
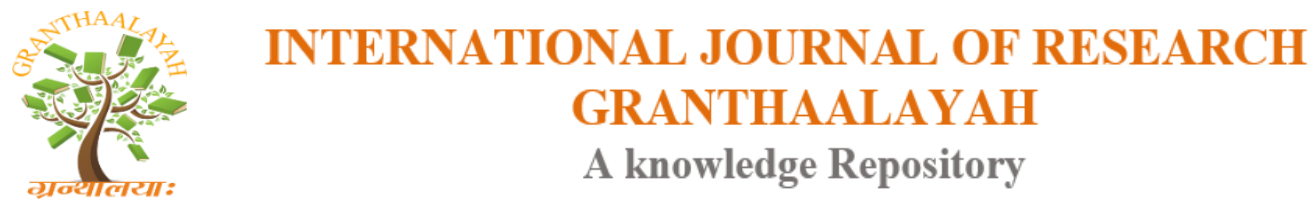

Social

\title{
THE INTER-LEARNING OF GEOMETRY IN MIDDLE ELEMENTARY EDUCATION STUDENTS IN ECUADOR
}

\author{
Helder Marcell Barrera Erreyes ${ }^{* 1}$, Jaqueline Alexandra Vaca Jiménez² ${ }^{2}$ Jenny Cecilia \\ Barrera Erreyes ${ }^{3}$, Jorge Francisco Abril Flores ${ }^{4}$, Teresa Marlene Barragán García \\ ${ }^{*}$ Pontifical Catholic University of Ecuador-Ambato, Technical University of Ambato, Ecuador \\ ${ }^{2}$ Pujilí Educational Unit \\ ${ }^{3}$ Educational Unit Vicente León \\ ${ }^{4}$ Technical University of Ambato, Ecuador \\ ${ }^{5}$ Department of English, Luis A. Martínez Superior Institute, Ecuador
}

\begin{abstract}
One of the main problems that in Ecuadorian education makes reference to the shortcomings in the quality of learning mathematics, specifically to the development of cognitive skills, thus overlooking motor skills and affective elements, in other words, there is not integral learning for life. Therefore, the aim is to diagnose the level of inter-learning, establishing a suitable strategy that is in line with performance-based skills for each period in geometry, methods and curriculum adaptations as well as apply the didactics for inter-learning in geometry with middle school students. In order to offer a series of applicable and practical tools that optimize the development of integral skills in students, specifically in topic-based work in geometry, the inductive method has been used because it adapts to the required needs in both the researching process and the structuring of the proposed strategy. While collecting data, it was possible to confirm that the contents of geometry are not applicable in practical life since they are taught theoretically. Moreover, it was detected that teachers have a need for alternative strategies which help them improve the quality of teaching. To conclude, with the appropriate use of teaching strategies, learning is made easier in geometry contents.
\end{abstract}

Keywords: Inter-Learning; Ecuadorian Education; Geometry; Strategy; Skills; Teaching.

Cite This Article: Helder Marcell Barrera Erreyes, Jaqueline Alexandra Vaca Jiménez, Jenny Cecilia Barrera Erreyes, Jorge Francisco Abril Flores, and Teresa Marlene Barragán García. (2018). "THE INTER-LEARNING OF GEOMETRY IN MIDDLE ELEMENTARY EDUCATION STUDENTS IN ECUADOR." International Journal of Research Granthaalayah, 6(4), 211-220. https://doi.org/10.29121/granthaalayah.v6.i4.2018.1646.

\section{Introduction}

The strategies used for the work of contents in Mathematics and specifically of Geometry and according to the curriculum of the Education Ministry of Ecuador appear limited within the 
teaching work, since this process contains deep elements related to reflection and analysis., in order that each content reaches a level of assimilation and important applicability in the student life, however the mechanical work and in some cases the rhetoric one causes that the problem is generated to the extent that the student does not assimilate the information adequately and therefore does not find practical sense to each one of them, in such virtue it is generated as a proposal of the development of a didactic strategy that facilitates the inter-learning of Geometry in students of the Middle Elementary Education.

The technology influence has been able to put aside certain resources or skills that can be applied in the work of interacting with Geometry contents, since they allow manipulation, analysis, synthesis and application without the intervention of elements that can be difficult to access for both students and teachers, the resources that are mentioned are the Geoboard, the Tangram, the Lego and of course the Origami technique, as a basis for the student to participate actively and effectively in the construction of his/her own knowledge. With the application of the materials described, it pretends to give the teacher a practical, applicable and simple tool that offers great possibilities to improve the quality of learning in Geometry.

The didactic strategy contains specific information in a clear and organized way in:

1.- Didactic foundation.

2.- Curricular design

3.- Basic resources

The didactic foundation is based on the Van Hiele model, according to the point made by Vargas, G. (2013), which states: "The Van Hiele geometric reasoning model is a teaching and learning model that provides the possibility to identify the forms of geometric reasoning and guidelines to follow in order to promote the attainment of higher levels of reasoning "(p.91), in this way results will be obtained after its application, for which adequate and precise activities have been designed for this purpose.

In this curricular design, plans were prepared according to the Curricular Update and Strengthening of the level of Middle Basic Education (5th, 6th and 7th grades) of Basic General Education in Geometry, in a clear and specific manner, easy to use and adaptive to any place.

The basic resources will be a tool that contributes to a relaxed, interesting and motivating work environment in order to achieve meaningful learning, in addition they are easy to elaborate with the children themselves, which becomes a fascinating experience.

The parameters of the evaluation are taken into account those suggested in the Curricular Update and Strengthening of Basic Education.

\section{State of the Art}

According to the National Assessment System (MEC, 2010), it is established that at the end of the Middle Basic General Education, the lowest percentage performance in the area of Mathematics corresponds to $21.64 \%$ while the excellent level corresponds to $3.23 \%$ which reflects a negative 
relationship around the level of achievements and that in fact needs to be strengthened based on the development of innovations especially in the inter-learning strategies used up until now.

Agreeing with (MINEDUC, 2010), says that "it was made from the evaluation of the curriculum of 1996, the accumulation of classroom experiences achieved in its application, the study of curricular models from other countries and, above all, the criterion of Ecuadorian specialists and Ecuadorian teachers "(page 7). This document offers viable methodological guidelines in teaching and learning, in order to contribute to the professional performance of teachers.

In the book (Crego, 2000) it states that the problem is generated by: "the teachers' lack of awareness of the uses of Geometry in everyday life and of the skills that it develops due to its intuitive, spatial and logical nature", because through this tool they give the teacher of basic education guidance about why geometry should be taught in school and with what conception they have to work at this level. (Brousseau, 1999), it highlights the postponement that this branch of Mathematics undergoes in favor of other topics which occupy time, in this way less time is devoted to this topic. In the thesis of the Technical University of Cotopaxi. (Sarabia, 2012) Expresses: "In short, the path followed through the different pedagogical currents shows that a methodological strategy is a valuable contribution, both for teachers and for students, consequently, contributes positively to the development of teaching and learning "(page 8). While it is true that active methods and techniques and strategies to implement creativity guide the development of classes, most of these are not adequately used in the teaching-learning process.

In the (Coll et al., 1993) text, "the Constructivism promotes meaningful student learning in class, the constructivist conception offers an integrating and powerful explanation about teaching and learning processes and, at the same time, provides criteria to analyze, plan, build and evaluate them "(page 18). This conception will be kept in mind for the development of this project because in constructivism we learn when we are able to elaborate our own learning thanks to the opportune advice of the teacher.

In the (Blanco Lorenzo, 2003) article, the students' conceptions for teachers in Spain on school geometry and teaching learning states that: "Two basic references serve as a guide in the research that we summarize: school geometry and its teaching / learning and analysis of students' conceptions for teachers in Spain "(p.1), these two aspects will be taken into account for the moment of selecting an adequate didactic strategy.

\section{Methodology}

\section{Diagnostic}

According to data available in (INEVAL, 2013) in which are presented the results of the tests "Ser Estudiante, applied in 2013, an analysis was developed on the performance of the students in the subjects of the applied evaluations"

This evaluation was carried out with a scale of National character and took into account about 45,000 students of fourth, seventh and tenth grade of elementary and third grades of high school. 
The results of "Ser Estudiante 2013" reveal the deficiencies that exist in subjects such as Mathematics, Science, Language and Literature, and Social Studies, nevertheless it was determined that the subject with the greatest learning deficit is Mathematics.

According to (INEVAL, 2013), in the fourth grade of basic education, 25\% of students have an insufficient grade, $30 \%$ in seventh, and $43 \%$ in tenth.

From the research carried out with the application of surveys to students, parents as well as interviews with teachers and authorities in the Pujilì School, it can be inferred that the development of contents in the area of Geometry does not have a clear methodology, active and participatory classes are a priority in the Pujilì School, not so much because of obligation but rather because the teaching and management staff tries to develop integral skills and above all to achieve the education standards that allow students to lay the foundations to continue with success the studies in the next levels.

An integral development is achieved when classes are working on the search for actions that potentiate cognitive, motor and affective factors, however there are certain limitations of a material nature, infrastructure and even methodology, given that the courses and events of teaching update are not suitable, though they have been supplemented by a self-preparation which has allowed to effectively develop the work in the classroom.

\section{Materials and Methods}

The research has the documentary-bibliographic modality, because it has the purpose of detecting, broadening and deepening different approaches, theories, conceptualizations and criteria of different authors on different aspects, for that it was used different sources such as documents, books, magazines, newspapers and internet.

The investigation is of field because for its realization we went to the place of the facts, from this way the direct information in Pujilí School was obtained.

While, for the data collection process, the survey was used to get information from a large group of people simultaneously and anonymously, a questionnaire of questions was designed for its application, which guaranteed that the data were real and true, process that constitutes a great contribution for the present investigation.

Whereas to work in a much more personalized and direct way especially with the directors of Pujilí School, the interview technique was chosen with the respective instrument such as the interview guide, this procedure allows managers to maintain a fluid dialogue with the opportunity to express criteria of great value for the subsequent analysis and interpretation of the results.

\section{Population and sample}

The universe of Middle Elementary Education in "Pujilí" school is made up of 90 students, 90 parents and 16 teachers, who give a total of 196 people it has been determined that they will work with the whole universe, so they do not will extract any sample. 


\title{
Method
}

The inductive method was applied: It constitutes a fundamental element for the analysis and interpretation of results obtained through data collection, since with these particular contributions general conclusions will be generated.

The empirical test is the fundamental criterion of the inductive method in order to evaluate a new theory, therefore the theory is accepted if it is tested empirically or otherwise it is rejected.

The inductive method proposes the following phases:

\section{Observation}

The observation is deployed in two stages, the first one during the diagnostic for the detection of the problem and the second in order to obtain the first impression, as well as tacit aspects during the field investigation with the application of interviews, surveys to the principal, teachers, parents and students of 5th, 6th and 7th grades of "Pujili'" School.

\section{Experimentation}

In this stage, the pilot test was applied in order to determine the validity of the didactic strategy proposed and thus confirm with these actions the validity of the procedure used.

\section{Comparison}

The comparison is developed when the data of the surveys made to students of the middle basic level and parents are tabulated, in this way, it is verified that the manipulation of objects and the construction of the same ones makes the student get involved much more in the learning of certain contents, for it has been fundamental the work with resources like the tangram, geoplane, legos and the origami technique, thus it has been possible to have a group of models that can even be part of an internal exhibition.

\begin{abstract}
ion
The process of abstraction is considered when the interpretation of results is made since data got by the object population of the research is obtained empirically and must be compared with theoretical-scientific elements that are part of the theoretical framework that sustains the investigative process.
\end{abstract}

\section{Generalization}

It constitutes the structuring of the general conclusions that emerge after all the researching process and its corresponding phases, as well as in the recommendations generated to solve the problem.

In addition, the Van Hiele Method was used: specifically, for the application in the proposal, which offers the opportunity to develop comprehensive skills in students in a motivating and attractive way in the treatment of each of the components mentioned.

\section{Results and Discussion}

Strategy them: Teaching guide for the teaching-learning of Geometry oriented to the Basic Middle Education. 


\section{Guide purpose}

To offer teachers of Pujilí School a guide of Didactic Strategies that support their work in the area of Geometry in order to achieve meaningful and productive learning.

\section{Didactic Foundation}

Before referring to the levels of the Van Hiele Model, it is necessary to reflect on the reasons why this methodology is implemented, because the model of educational management in Ecuador basically seeks (MINEDUC, 2010) "Renew processes and automate procedures to improve customer service ", with this purpose a high deconcentrating of educational management is designed, in the new management model it is intended that the procedures will no longer be carried out in a centralized manner, but that users will be able to perform them in nearby places to their home.

The New Management Model divides the national territory into zones, districts and circuits, to facilitate the obtaining of educational services in central locations and close to the citizens, in this way it provides greater efficiency, speed and coverage to its users.

However, in the scope of the development of class processes, we have not really seen great innovations, we must not forget that since 1997 we have tried to change the pedagogical model that among its main characteristics is that the students were memorizers, less participative, hardly developed their critical and reflective skills, then constructivism that seeks the opposite, that is to say that students are the builder of their own knowledge, however in practice this end has not been fully achieved, especially in what is refers to the area of Mathematics and in a specific way of Geometry, in such a way the Van Hiele Model (Vargas, 2013) offers the opportunity to develop in students integral skills in a motivating and attractive way in the treatment of each one of the components mentioned.

In addition, an analysis was made of the teaching methods and processes established in the Pedagogical Bulletins (1994), Guide 2 CEDMI (1998), the precisions for teaching and learning in the area of Mathematics of the Geometry block described in the Update and Strengthening Curriculum of the Basic General Education (BGE). (2010), in which a process for teaching Geometry is not specified, so this is a fundamental argument to establish that the suggested methodology is applicable.

Levels of the Van Hiele model:

The levels are five and are usually named with the numbers from 1 to 5, however, the notation from 0 to 4 is more used. These levels are named as follows:

LEVEL 0: Visualization or recognition

LEVEL 1: Analysis

LEVEL 2: Sorting or classification

LEVEL 3: Formal deduction

LEVEL 4: Rigor

The results obtained previous to the application of the pilot test with respect to the analysis of geometric spaces are the following: $37 \%$ of students do it in a reasoned way, while $63 \%$ do not. 
It should be noted that the reasoning, analysis on theoretical-scientific knowledge makes education and academic training have meaning, otherwise we would talk for a long time of lines, forms, spaces and other elements without any practical or reflective sense, transforming education in a simple fact, cold and inapplicable in the present and future life of the students.

This information is contrasted with the results obtained after applying the didactic strategy as a pilot test for the Geometry inter-learning, in students of Middle Basic Education of Pujili School of Pujilí canton, demonstrating that there are significant advances in the educational process, like this:

Of a total of 90 students surveyed 89 that correspond to $99 \%$ mention that the analysis of geometric spaces does so in a reasoned way, while 1 student corresponding to $1 \%$ mentions not doing so.

Therefore, the reasoning becomes a fundamental part of the work in geometry since the use of the proposed strategy as well as the planned resources requires the student to support their knowledge based on the analysis of the geometric processes applied in the proposed strategy.

\section{Curricular Planning}

In the curricular design, plans were prepared according to the Curricular Update and Strengthening of the level of Middle Elementary Education (5th, 6th and 7th grades) of Basic General Education in Geometry, in a clear and specific manner, easy to use and adaptive. to any medium.

Basic information is provided for each of the resources included in the proposal generated, however specific and detailed elements of both its application and evaluation are included in each of the skill plans that follow.

\section{Conclusions}

- It is feasible to implement a didactic strategy for Geometry inter-learning in students of Middle Elementary Education level.

- It has been possible to investigate and systematize scientific theoretical information that supports the problem and guarantees the conceptualization of it.

- The level of Geometry inter-learning in students of Middle Basic Education of School, is deficient and does not achieve significant learning.

- After having analyzed the teaching methods and processes established in the Pedagogical Bulletins (1994), Guide 2 CEDMI (1998), the precisions for teaching and learning in the area of Mathematics of the Geometry block described in the Curriculum Update and Strengthening of the BGE. (2010), in which a process for teaching of Geometry is not specified, it has been established that the appropriate strategy in accordance with the skills with performance criterion of the curricular Geometric block, methods and curricular adaptations, for its applicability in the Geometry inter-learning, in students of Middle Basic Education is the curricular design proposed with the use of the levels proposed by Van Hiele.

- After applying the didactic strategy as a pilot test for Geometry inter-learning, in Middle Elementary students it has been determined that there are significant advances in the educational process. 


\section{References}

[1] Avanzini, G. (1998). La pedagogía hoy. FCE. México.

[2] Blanco Lorenzo, M. B. (02 de julio de 2003). Google Académico. Obtenido de http://dialnet.unirioja.es/servlet/articulo?codigo $=2092516$

[3] Borbón, S. F. (1997). Estrategias para implementar la creatividad. Colombia: Cargraphics.

[4] Brousseau. (1999). Educación y Didáctica de las Matemáticas. México.

[5] Campos, Y. (2000). "Estrategias didácticas apoyadas en tecnología" DGENAM. México D.F.

[6] CEDMI (1998). Guía 2 "Métodos, técnicas y procedimientos activos"

[7] Coll y otros, C. (1993). EL Constructivismo en el Aula. Barcelona: Graó, de Servies Pedagógics.

[8] Crego, A. M. (2000). Razones para enseñar Geometría en la Educación Básica. Argentina: Novedades Educativas.

[9] Esteban, Manuel. (2008) "Estrategias de aprendizaje" Editorial RED. Murcia-España

[10] Fabra, M. (1994) Técnicas de grupo para la cooperación. Ediciones CEAC. Barcelona-España.

[11] Feo, R. (2009). "Estrategias Instruccionales para Promover el Aprendizaje Estratégico" Mc Graw Hill. México

[12] García, S. (2008) "La enseñanza de la geometría” INEE. México D.F.

[13] Lastra, S. (2005) "Propuesta metodológica para la enseñanza-aprendizaje de la geometría" Uchile. Santiago de Chile.

[14] Latorre, M. (2013) “Estrategias y técnicas metodológicas”. VISIONPCPERÚ Ediciones. LimaPerú.

[15] MEC. (2010). Capacitación Inicial del área de Matemática. Quito: Don Bosco.

[16] MEC. (1994). Boletines Pedagógicos

[17] MINEDUC (2010) “Actualización y Fortalecimiento curricular”. Quito-Ecuador.

[18] MINEDUC. (2010). Actualización y Fortalecimiento Curricular dela Educación General Básica. Quito: Imprenta Don Bosco.

[19] MINEDUC. (2012) "Estándares de Calidad Educativa" Editogran. Quito-Ecuador

[20] OCÉANO. (2005). Biblioteca Práctica del docente tomo 2. Barcelona (España): Océano.

[21] Panza M. (1990). "Fundamentación de la didáctica". Editorial Gernica. México

[22] Pedrosa, J. (2013) "Concurso de español” RedElé. España.

[23] Pimienta, J. (2012). "Estrategias para Aprender a Aprender". Pearson. México.

[24] Posso, M. (2011). Proyectos, Tesis y Marco Lógico. Quito: Noción Imprenta.

[25] Sarabia, R. (2012). Estrategias Metodológicas para el perfeccionamiento del proceso de enseñanza aprendizaje de Matemática, en los séptimos años de educación general básica. Latacunga: UTC.

[26] Solá, Juan. (1998) "Pedagogía en píldoras" Editorial Trillas, México D.F.

[27] Vargas, G. (2013) "El modelo de Van Hiele y la enseñanza de la Geometría" UNICIENCIA. Costa Rica.

[28] Vicepresidencia de la República del Ecuador, MINEDUC (2011). Estrategias pedagógicas para atender las necesidades educativas especiales en la educación regular.

\footnotetext{
*Corresponding author.

E-mail address: ankitasingh2021@ gmail.com
} 
Annexes

Curricular Planning proposal:

\begin{tabular}{|c|c|c|c|c|c|c|c|}
\hline & & \multicolumn{4}{|c|}{ PUJILI SCHOOL } & \multicolumn{2}{|c|}{$\begin{array}{l}\text { SCHOOL YEAR } \\
20157-2018\end{array}$} \\
\hline \multicolumn{6}{|c|}{ MICRO CURRICULAR PLANNING PER BLOCK } & No BLOCK & 1 \\
\hline \multirow{3}{*}{ 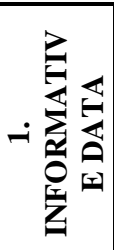 } & \multirow{2}{*}{ TEACHER: } & \multirow{2}{*}{ AREA/ SUBJECT } & \multirow{2}{*}{$\begin{array}{l}\text { GRADE } \\
\text { /COURSE }\end{array}$} & \multicolumn{2}{|c|}{ TIME } & \multicolumn{2}{|c|}{ LASTING } \\
\hline & & & & WEEKS & PERIODS & BEGINNING & FINAL \\
\hline & & MATHEMATICS & FIFTH GRADE & 6 & $7 / 42$ & & \\
\hline \multirow{7}{*}{ 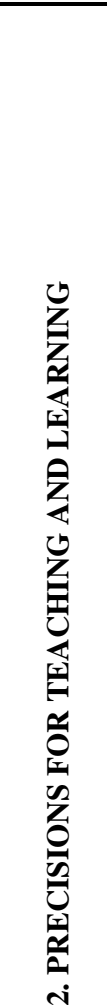 } & \multicolumn{2}{|c|}{$\begin{array}{c}\text { INTEGRATED CURRICULAR } \\
\text { AXIS }\end{array}$} & \multicolumn{2}{|c|}{$\begin{array}{l}\text { AXIS OF LEARNING / } \\
\text { MACRO SKILLS }\end{array}$} & \multicolumn{3}{|c|}{$\begin{array}{l}\text { TRANSVERSAL AXIS } \\
\text { /INSTITUTIONAL }\end{array}$} \\
\hline & \multicolumn{2}{|c|}{$\begin{array}{l}\text { Develop logical and critical thinking to } \\
\text { interpret and solve life problems. }\end{array}$} & \multicolumn{2}{|c|}{$\begin{array}{l}\text { Reasoning, demonstration, } \\
\text { communication, connections and / } \\
\text { or representation. }\end{array}$} & \multicolumn{3}{|c|}{ Good Living: Interculturality } \\
\hline & \multicolumn{2}{|c|}{ BLOCK TITLE / MODULE: } & \multicolumn{5}{|c|}{ BLOCK OBJECTIVE / MODULE } \\
\hline & \multicolumn{2}{|c|}{ Ecuador: diversity integration } & \multicolumn{5}{|c|}{ Recognize parallel, perpendicular, secant and angled lines } \\
\hline & \multirow{3}{*}{$\begin{array}{l}\text { LEARNING } \\
\text { STANDARS }\end{array}$} & DOMAIN A & \multicolumn{5}{|c|}{$\begin{array}{l}\text { NUMBERS AND FUNCTIONS: It locates in the Cartesian plane objects } \\
\text { from ordered pairs, formed by natural numbers, fractions and decimals. } \\
\text { Establish relations of order and recognize positional value. }\end{array}$} \\
\hline & & DOMAIN B & \multicolumn{5}{|c|}{ GEOMETRY: Classify and construct angles, triangles, quadrilaterals. } \\
\hline & & DOMAIN C & \multicolumn{5}{|c|}{$\begin{array}{l}\text { Justify procedures used in the resolution and formulation of situations or } \\
\text { geometric problems of measurement and estimation. }\end{array}$} \\
\hline
\end{tabular}




\begin{tabular}{|c|c|c|c|c|c|}
\hline \multirow{2}{*}{$\begin{array}{l}\text { SKILLS WITH } \\
\text { PERFORMANCE } \\
\text { CRITERIA }\end{array}$} & \multirow{2}{*}{$\begin{array}{l}\text { METHODOLOGICAL } \\
\text { STRATEGIES }\end{array}$} & \multirow[b]{2}{*}{ RESOURCES } & \multicolumn{3}{|c|}{ ASSESMENT } \\
\hline & & & \multicolumn{2}{|c|}{$\begin{array}{l}\text { KEY INDICATORS } \\
\text { OF EVALUATION }\end{array}$} & $\begin{array}{l}\text { TECNHIQUES } \\
\text { AND TOOLS } \\
\text { EVALUATION }\end{array}$ \\
\hline $\begin{array}{l}\text { GEOMETRIC } \\
\text { SYSTEM } \\
\text { Parallel, } \\
\text { perpendicular and } \\
\text { secant lines } \\
\text { Graphic } \\
\text { representation } \\
\text { Recognition }\end{array}$ & $\begin{array}{l}\text { VAN HIELE METHOD } \\
\text { STAGES } \\
\text { Visualization or recognition } \\
\text { Observation of perpendicular and } \\
\text { secant straight lines in objects of } \\
\text { nature. } \\
\text { Practical location of lines in the } \\
\text { geoplane. } \\
\text { Analysis } \\
\text { Draw the figures of the Geoplane } \\
\text { in each of the notebooks. } \\
\text { Determination of properties of } \\
\text { each of the lines located in the } \\
\text { geoplane. } \\
\text { Analyze student text information } \\
\text { Sorting or classification } \\
\text { Discriminate the specific } \\
\text { characteristics of each of the lines } \\
\text { to carry out the required } \\
\text { classification. } \\
\text { Formal deduction } \\
\text { Conceptualize and exemplify } \\
\text { each of the lines. } \\
\text { Develop the activities of the } \\
\text { workbook. }\end{array}$ & $\begin{array}{l}\text { Workbook } \\
\text { Notebook } \\
\text { work } \\
\text { Geoplane } \\
\text { Leagues }\end{array}$ & $\begin{array}{l}\text { Recognize } \\
\text { perpendic } \\
\text { secant line } \\
\text { figures }\end{array}$ & $\begin{array}{l}\text { parallel, } \\
\text { lar and } \\
\text { in flat }\end{array}$ & $\begin{array}{l}\text { Technique: } \\
\text { Test } \\
\text { Tool: } \\
\text { Exercise }\end{array}$ \\
\hline \multicolumn{4}{|c|}{ 4. BIBLIOGRAPHY / WEB: } & \multicolumn{2}{|c|}{ 5. OBSERVATIONS } \\
\hline \multicolumn{4}{|c|}{$\begin{array}{l}\text { Ministerio de Educación, Actualización y Fortalecimiento Curricular de la Educación } \\
\text { General Básica, 2010, Don Bosco Quito } \\
\text { Ministerio de Educación, Estándares de Calidad Educativa, Aprendizaje, Gestión Escolar, }\end{array}$} & & \\
\hline
\end{tabular}

